Proceeding ICOGISS 2019

Page 910-919. ISBN: 978-602-6 988-75-1

Web Jurnal Online: jurnal.unmuhjember.ac.id By: Dery Shafwan; Nurul Qomariah; Jekti Rahayu

The Influence of Quality of Service, Facilities and Location of Customer Satisfaction

\title{
THE INFLUENCE OF QUALITY OF SERVICE, FACILITIES AND LOCATION OF CUSTOMER SATISFACTION
}

\author{
Dery Shafwan P. N, Nurul Qomariah, Jekti Rahayu \\ Universitas Muhammadiyah Jember \\ Email: derryshafwan@gmail.com, jektirahayu@unmuhjember.ac.id, \\ nurulqomariah@unmuhjember.ac.id (Coresponding author)
}

\begin{abstract}
This study aims to determine the effect of service quality, facilities and location on customer satisfaction at SPBU 54.681.08 Tanggul Kulon Jember. The population in this study were all gas station customers, namely 95 respondents with non probability sampling techniques. The analysis tool uses multiple linear regression. The results showed that service quality $(0.231)$, facilities (0.769) and location (0.234) had a significant influence on customer satisfaction. $T$ test results showed that the variable service quality $(0.039)$, facilities $(0,000)$ and location (0.006) partially had a significant effect on customer satisfaction at the Tanggul Kulon Jember gas station.
\end{abstract}

Keywords: Service quality, facilities, location and customer satisfaction. 
Proceeding ICOGISS 2019

Page 910-919. ISBN: 978-602-6 988-75-1

Web Jurnal Online: jurnal.unmuhjember.ac.id By: Dery Shafwan; Nurul Qomariah; Jekti Rahayu

The Influence of Quality of Service, Facilities and Location of Customer Satisfaction

\section{INTRODUCTION}

Nowadays competition in the business world is increasingly competitive. This can be seen from the many emerging companies, both those engaged in services or goods. The products produced by the company are also very diverse. One product is fuel oil. Oil fuel is one of the forms of energy which is sufficiently basic for humans. Along with the emergence of science and technology, fuel becomes a primary need that is indispensable for humans in supporting their various life activities. The user of fuel oil is needed for daily needs such as transportation in general. Transportation is a useful tool to move goods or people in a certain quantity, to a certain place, in a certain time (Tjiptono \& Candra, 2012).

Transportation in Indonesia has been highly developed such as land, sea and air transportation. Land transportation is currently being developed such as two-wheeled vehicles or motorcycles, four-wheeled vehicles or cars, buses, trucks and others. Pertamina is a domestic company that supplies domestic fuel needs. For this reason Pertamina continues to develop and expand gas stations in Indonesia in order to expand Pertamina's reach to remote areas of the country. The Oil and Gas Downstream Regulatory Agency (BPH Migas) states the number of Public Fuel Filling Stations (SPBU) in Indonesia is still relatively low, the number of gas stations scattered throughout Indonesia is recorded at around 6,000 to 7,000 units. The number is still relatively small compared to the total population of Indonesia which reaches nearly 260 million people. The ratio of gas stations to the population is still far less than one gas station serving 35,000 people. In addition to developing the number of Pertamina gas stations it also continues to develop new service standards to ensure consumers get the best service. In this service standard, consumers have a very high role. Pertamina itself has five elements of service standards including service staff who are highly trained and motivated, guarantee quality and quantity, maintained equipment, consistent physical format and product offerings and value-added services with operators who always implement $3 \mathrm{~S}$ (Greetings, Smiles, Sapa).

Although the number of gas stations in Indonesia does not meet the population ratio, every organization engaged in the management of gas stations (SPBU) must pay attention to customer satisfaction. Gas Station (SPBU) 54.681.08 Tanggul Kulon Village Tanggul District Jember Regency is a gas station that has operated since 1985. There are several facilities available at the 54,681.08 gas station such as: canteen, ATM center, mosque, toilets, post filling radiator water and wind pumps. The Kulon Jember embankment gas station has 4 refueling posts consisting of pertalite, Pertamax, Pertamax turbo and bio diesel. At present competition between gas stations is increasing. This increased competition results in fluctuations in fuel sales. The following data were obtained regarding the financial statements for the last 2 years in 2016-2017. 
Proceeding ICOGISS 2019

Page 910-919. ISBN: 978-602-6 988-75-1

Web Jurnal Online: jurnal.unmuhjember.ac.id By: Dery Shafwan; Nurul Qomariah; Jekti Rahayu

The Influence of Quality of Service, Facilities and Location of Customer Satisfaction

Table 1. SPBU Financial Report 54.681.17 for the period of 2016 - 2017

\begin{tabular}{|c|c|c|c|}
\hline \multirow[t]{3}{*}{ No } & \multirow[t]{3}{*}{ Month } & \multicolumn{2}{|c|}{ Income } \\
\hline & & \multicolumn{2}{|c|}{ Year } \\
\hline & & 2016 & 2017 \\
\hline 1 & January & Rp. 132.000 .000 & Rp. 193.000 .000 \\
\hline 2 & February & Rp. 129.000.000 & Rp. 201.000.000 \\
\hline 3 & March & Rp. 138.000 .000 & Rp. 210.000 .000 \\
\hline 4 & April & Rp. 141.000 .000 & Rp. 212.000 .000 \\
\hline 5 & May & Rp. 139.000.000 & Rp. 204.000.000 \\
\hline 6 & June & Rp. 142.000 .000 & Rp. 219.000.000 \\
\hline 7 & July & Rp. 169.000.000 & Rp. 217.000 .000 \\
\hline 8 & August & Rp. 164.000.000 & Rp. 213.000.000 \\
\hline 9 & September & Rp. 154.000 .000 & Rp. 220.000 .000 \\
\hline 10 & October & Rp. 159.516.000 & Rp. 216.000.000 \\
\hline 11 & November & Rp. 163.514 .000 & Rp. 217.000 .000 \\
\hline 12 & December & Rp. 171.665.800 & Rp. 222.000 .000 \\
\hline
\end{tabular}

Source: SPBU 54.681.08 Tanggul Kulon Jember (not published)

In table 1. it can be explained that during the last 2 years (2016-2017) 54,681.08 gas stations in Jember experienced fluctuating sales. Many factors cause the level of fuel sales at the Kulon embankment station in Jember to experience fluctuations. Based on this problem, the SBPU management is demanded to continue to provide the best service to its customers. This is very important to be done by every service provider organization so that customers who are served get the best service. Good service quality can increase customer satisfaction.

Customer satisfaction is a response from consumers on the performance that has been given in accordance with customer expectations (Kotler, 2007). According to (Lupiyoadi, 2013), customer satisfaction is the level of feeling in which a person states the results of the comparison of the performance of products received and expected. According to (Lupiyoadi, 2013) customer satisfaction is the level of feeling in which a person states the results of the comparison of the performance of products (services) received and expected. Customer satisfaction is an attitude that is decided based on the experience gained (Kotler, 2007).

The importance of customer satisfaction for businesses is to maintain the long-term viability of the business. Customer satisfaction is the company's benchmark for survival. If the customer is not satisfied of course the customer will not come back again and might also be able to complain about his dissatisfaction with other customers, of course this will be a threat to the entrepreneur (Qomariah, 2016). Customer satisfaction can not only be achieved by the quality of service, but there are other factors that can support the fulfillment of customer satisfaction. So that the presence of these factors can make businesses think more by providing something new in order to make customers interested (Tjiptono \& Candra, 
Proceeding ICOGISS 2019

Page 910-919. ISBN: 978-602-6 988-75-1

Web Jurnal Online: jurnal.unmuhjember.ac.id By: Dery Shafwan; Nurul Qomariah; Jekti Rahayu

The Influence of Quality of Service, Facilities and Location of Customer Satisfaction

2012). Many factors can make consumers satisfied with the products offered. One of them is the quality of service provided by the service provider. Service quality is the expected level of excellence and control over the level of excellence to meet customer desires (Tjiptono, 2007). Te quality of service is a global attribute of the company and is a customer's consideration of the overall success or superiority of the company (Kotler \& Amstrong, 2008). The quality of service expected by consumers includes adequate facilities, good service, comfort, safety, calm and satisfying results so that management must think about how good service quality at this time can continue to grow for the smooth future. High customer satisfaction is caused by maximum service quality and if the quality of service provided is poor then consumer expectations will never be achieved so that customers will disappear one by one, this means the company will lose customers. Thus only companies that are able to provide high customer satisfaction alone will be able to compete and survive for life and further develop for the survival of the company (Mowen \& Minor, 2001). Research that connects service quality and customer satisfaction has been done a lot. Research (Subagiyo, 2015), (Mulyawan \& Rinawati, 2016), (Safitri, Rahayu, \& Indrawati, 2016), (Sutrisno, Cahyono, \& Qomariah, 2017), (Verriana \& Anshori, 2017), (Anggriana, Qomariah, \& Santoso, 2017), (Setyawati, Rifai, \& Sasmito, 2018), stated that good service quality can increase customer satisfaction. Research (Qomariah 2012) states that service quality has no impact on customer satisfaction. Facility factors are factors that can also increase customer satisfaction. Facilities are all things that are physical equipment provided by the service seller to support consumer comfort (Kotler \& Amstrong, 2008). Facilities are important things to consider in a service business, especially those that are closely related to what is felt by consumers, because in a service business consumers' assessment of a company is based on what they get after using services. Therefore services are performance and cannot be felt like goods, then customers tend to pay attention to facts related to services as proof of quality. According to (Tjiptono, 2007). the facility is the appearance, the ability of infrastructure and the condition of the surrounding environment in showing its existence to the external which includes the physical facilities of equipment and equipment. Physical facilities are one indicator of whether or not the quality of a service is closely related to the formation of customer perceptions, with a good facility the consumer will be interested in the services offered and make a purchase of the services offered. (Lupiyoadi, 2013). Research (Puspita \& Santoso, 2018) and (Yunus \& Budiyanto, 2013) state that fasilities influences on satisfaction. Business location is usually very influential on the sustainability of a business. The location of the company is also one of the factors that can increase customer satisfaction. Location is also a factor that determines the success of a business. Location is a decision made by a company relating to where operations and staff will be located (Lupiyoadi, 2013). Location plays an important role in doing business. Because it is related to the location of the business with the center of the crowd, easy to reach, safe, and the availability of a large parking area, in general consumers prefer. One strategy that needs to be considered in a company is the choice of business location, location selection is needed when the company 
Proceeding ICOGISS 2019

Page 910-919. ISBN: 978-602-6 988-75-1

Web Jurnal Online: jurnal.unmuhjember.ac.id By: Dery Shafwan; Nurul Qomariah; Jekti Rahayu

The Influence of Quality of Service, Facilities and Location of Customer Satisfaction

establishes a new business to expand existing businesses or move existing location businesses to new ones (Tjiptono \& Candra, 2012). If there is an error in choosing the location / place, it will have a big influence on the daily survival of the gas station. The closer the location to the community the more customers feel satisfied with the company because the location is also included in the factors of customer satisfaction. Research (Rahmadani, Suardana, \& Samudra, 2017) and (Tarinda, Zaini, \& Zebua, 2018) state that location influences customer satisfaction. Based on the background, underlying theories and empirical studies, the purpose of this study was to analyze the influence of service quality, facilities and location on customer satisfaction at SPBU 54,681.08 Tanggul Kulon Jember. While the hypotheses in this study are:

H1: Service Quality Significantly Influences Customer Satisfaction

H2: Facilities have a Significant Effect on Customer Satisfaction.

H3: Location Has a Significant Impact on Customer Satisfaction.

\section{RESEARCH METHODS}

This research is a causality research that aims to measure the strength of the relationship between two or more variables, also shows the direction of the relationship between the independent and dependent variables. In other words causality research questions the problem of cause and effect (Ferdinand, 2006). The population in this study is a population which by nature is a homogeneous population. And the population in this study were customers of SPBU 54,681.08 Tanggul Kulon Jember. . The determination of the sample in this study was determined based on the number of research indicators. The number of samples is equal to the number of indicators multiplied by 5 to 10 . This study uses 19 indicators and uses a factor of 5 times because the research indicators only amount to 19 indicators, then the number of samples of this study is set at $19 \times 5=95$ then rounded up to 95 respondents. The sampling technique in this study uses non probability sampling. Nonprobability sampling is a sampling technique that does not provide equal opportunity / opportunity for each element or member of the population to be selected as a sample (Sugiyono, 2013). This study uses the independent variables and the dependent variable. The independent variable consists of: service quality, facilities and location while the dependent variable is customer satisfaction.

Validity test is used to measure the validity of a measuring instrument. Reliability test is used to measure the reliability of a measuring instrument used (Ghozali, 2005). To determine the effect of independent variables on the dependent variable used is multiple regression analysis (Sugiyono, 2013).. The regression equation model used can be formulated as follows: $Y=\alpha$ $+\beta_{1} X_{1}+\beta_{2} X_{2}+\beta_{3} X_{3}+e$

The $t$ test is used to test the significance of the constants of each independent variable, whether the independent variable really has a partial effect on the dependent variable, namely customer satisfaction. 
Proceeding ICOGISS 2019

Page 910-919. ISBN: 978-602-6 988-75-1

Web Jurnal Online: jurnal.unmuhjember.ac.id By: Dery Shafwan; Nurul Qomariah; Jekti Rahayu

The Influence of Quality of Service, Facilities and Location of Customer Satisfaction

\section{RESULTS AND DISCUSSION}

\section{Descriptive Statistics Analysis Results}

Based on gender, the results of the statistical description are known that there are more male respondents than female respondents. Respondents were male as many as 52 respondents or $54.7 \%$ and respondents were female as many as 43 respondents or $54.3 \%$ of the total respondents who were 95 gas station customers 54,681.08 Tanggul Kulon-TanggulJember. Based on the age of the respondents, it can be seen that respondents aged 20-29 years are 17 respondents or $17.9 \%$, while respondents aged 30-39 years have a total of 20 respondents or $21.1 \%$ and respondents aged $40-49$ years are 35 respondents or $36.8 \%$, respondents aged 50-59 years as many as 23 respondents or $24.2 \%$ of the total 95 respondents.

\section{Validity test}

The validity test in this study was measured by conducting a bivariate correlation between each indicator score with the construct score or variable, then the results of the correlation were compared with a critical level of 5\% (0.05). If the correlation of each statement score with the total score shows a significant result or more than 0.2017 then the statement item is declared valid. Based on the calculation results, it can be seen that all statement items have a greater $r$-count value with $r$-table (0.2017). It can be concluded that each statement item in the questionnaire can be proven to be valid.

\section{Reliability Test}

Reliability tests were performed using the Cronbach Alpha method. A variable is said to be reliable if the variable gives a Cronbach Alpha value>0.60. Statistical calculation results show that the service quality variable $(\mathrm{X} 1) 0,661>0,60$, facility variable (X2) 0,662>0,60, location variable (X3) 0,734>0,60, and customer satisfaction variable (Y) 0,762>0,60 Thus it can be concluded that all statement items in the questionnaire can be trusted because the measurement results are relatively consistent even though the statement is given twice or more to different respondents so that this questionnaire can be used for further research that uses the same variable.

\section{Multiple Linear Regression Analysis}

Multiple linear analysis is a model used to analyze the effect of various independent variables on one dependent variable. The analysis is used to find out how much influence more than one independent variable has on one dependent variable. Based on the estimation of multiple linear regression with IBM SPSS software, the following results are obtained: $\mathrm{Y}=$ $1.878+0,231 \mathrm{X} 1+0,769 \mathrm{X} 2+0,234 \mathrm{X} 3$, 
Proceeding ICOGISS 2019

Page 910-919. ISBN: 978-602-6 988-75-1

Web Jurnal Online: jurnal.unmuhjember.ac.id By: Dery Shafwan; Nurul Qomariah; Jekti Rahayu

The Influence of Quality of Service, Facilities and Location of Customer Satisfaction

\section{DISCUSSION}

\section{Effect of Service Quality on Customer Satisfaction}

Based on the results of statistical calculations it is known that service quality has a positive and significant effect on customer satisfaction. For the t test the significance value is less than 0.05 , that is 0.039 , it shows that the quality of service can cause significant customer satisfaction. The results of the study indicate that the better the quality of service provided to customers at the Kulon embankment station in Jember, the higher the level customer satisfaction. The quality of service at the Kulon embankment gas station is the same as expressed also by (Tjiptono, 2010) the quality of service is the expected level of excellence and control over the level of excellence to meet customer desires. Improving the quality of service excellence at the Kulon embankment filling station, such as increasing reliability when filling fuel and others, so that customers will be satisfied with the quality of service at the Tanggul Kulon filling station. Research (Subagiyo, 2015), (Mulyawan \& Rinawati, 2016), (Safitri et al., 2016), (Sutrisno et al., 2017), (Verriana \& Anshori, 2017), (Anggriana et al., 2017), (Setyawati et al., 2018), stated that good service quality can increase customer satisfaction. Research (Qomariah 2012) states that service quality has no impact on customer satisfaction.

\section{Effect of Facilities on Customer Satisfaction}

Based on testing it can be concluded that the facility has a positive and significant effect on customer satisfaction. $T$ test results show the significance value for the facility variable is less than 0.05 , namely 0,000 , then it shows that the facility can cause significant customer satisfaction. The results of the study indicate that the better the facilities provided to customers at the Tanggul Kulon Jember gas station, the higher the level of customer satisfaction. According to (Lupiyoadi, 2013) the facility is the appearance, the ability of infrastructure and the condition of the surrounding environment in showing its existence to the external which includes physical facilities (buildings) equipment and equipment. Physical facilities at the Kulon embankment gas station can be said to be in accordance with the standards, with that if the facility is good it will increase customer satisfaction. Research (Puspita \& Santoso, 2018) and (Yunus \& Budiyanto, 2013) state that fasilities influences on satisfaction.

\section{Effect of Location on Customer Satisfaction}

Based on testing concluded that location has a positive and significant effect on customer satisfaction. The results of the $t$ test calculations show that the significance value of the location variable is smaller than 0.05 which is 0.006 , then it shows that location can cause significant customer satisfaction. The results indicate that the more precise the location specified at the Tanggul Kulon Jember gas station, the higher the level of customer satisfaction. One strategy that needs to be considered in a company is the choice of business location, location selection is required when the company establishes a new business to expand existing businesses or move existing local businesses to new ones (Lupiyoadi, 2013). 
Proceeding ICOGISS 2019

Page 910-919. ISBN: 978-602-6 988-75-1

Web Jurnal Online: jurnal.unmuhjember.ac.id By: Dery Shafwan; Nurul Qomariah; Jekti Rahayu

The Influence of Quality of Service, Facilities and Location of Customer Satisfaction

Research (Rahmadani et al., 2017) and (Tarinda et al., 2018) state that location influences customer satisfaction.

\section{CONCLUSIONS AND RECOMMENDATIONS}

Service quality has a positive and significant effect on customer satisfaction. These results also indicate that the higher the quality of service the customer satisfaction will experience a significant increase. Facilities have a positive and significant impact on customer satisfaction. This result also shows that the better the facilities, the customer satisfaction will increase significantly. Location has a positive and significant effect on customer satisfaction. This result also shows that the better the location in the Tanggul Kulon Jember gas station, the customer satisfaction will increase significantly.

Based on the analysis that has been done in this study, then there are some suggestions as follows: a) The company should provide quality service in accordance with customer desires so as to increase high customer satisfaction, b) Company facilities should be further improved and made improvements, so that customers can feel comfortable and satisfied when making fuel purchases at the Tanggul Kulon Jember gas station, c) the company should really understand how strategic and appropriate location and ensure that customer satisfaction can be felt by the company and the customer, d) researchers are expected to further add variables other variables to find out more factors that influence customer satisfaction. It aims to find out more complex problems that can affect customer satisfaction in order to improve research results. In addition, further researchers can also add samples by conducting research in other institutions. This is to obtain different results so that it can be used as material for comparison. 
Proceeding ICOGISS 2019

Page 910-919. ISBN: 978-602-6 988-75-1

Web Jurnal Online: jurnal.unmuhjember.ac.id By: Dery Shafwan; Nurul Qomariah; Jekti Rahayu

The Influence of Quality of Service, Facilities and Location of Customer Satisfaction

\section{REFERENCE}

Anggriana, R., Qomariah, N., \& Santoso, B. (2017). Pengaruh Harga, Promosi, Kualitas Layanan Terhadap Kepuasan Pelanggan Jasa Ojek Online "OM-JEK” Jember. Jurnal Sains Manajemen Dan Bisnis Indonesia, 7(2), 137-156.

Ferdinand, A. (2006). Metode Penelitian Manajemen:Pedoman Penelitian Untuk Penulisan Skripsi, Thesis, dan Disertasi Ilmu Manajemen. Semarang: Badan Penerbit Universitas Diponegoro.

Ghozali, I. (2005). Aplikasi Analisis Multivariate dengan Program SPSS. Semarang: Edisi Kelima Badan Penerbit Universitas Diponegoro.

Kotler, P. (2007). Manajemen Pemasaran. Jakarta: PT. Prenhalindo.

Kotler, P., \& Amstrong, G. (2008). Prinsip-Prinsip Pemasaran. Jakarta: Penerbit Erlangga.

Lupiyoadi, R. (2013). Manajemen Pemasaran. Jakarta: Salemba Empat.

Mowen, J. C., \& Minor, M. (2001). Perilaku Konsumen. Jakarta: Erlangga.

Mulyawan, A., \& Rinawati. (2016). Pengaruh Kualitas Layanan Akademik Terhadap Kepuasan Mahasiswa Serta Implikainya Pada Loyalitas Mahasiswa, 10(2), 119-131.

Puspita, R. M., \& Santoso, S. (2018). Pengaruh Kualitas Pelayanan Dan Fasilitas Pendukung Terhadap Kepuasan Pelanggan Stasiun Lempuyangan Yogyakarta. Eksis: Jurnal Riset Ekonomi Dan Bisnis, 13(1), 69-80. https://doi.org/10.26533/eksis.v13i1.145

Qomariah, N. (2016). Marketing Adactive Strategy. Jember: Cahaya Ilmu. Retrieved from https://www.researchgate.net/publication/326623130_Marketing_Adactive_Strategy

Rahmadani, F., Suardana, I. M., \& Samudra, H. (2017). Pengaruh Kualitas Pelayanan, Produk, Harga Dan Lokasi Terhadap Loyalitas Pelanggan Dengan Kepuasan Pelanggan Sebagai Variabel Intervening Pada Ud. Eva Group Mataram. VALID Jurnal Ilmiah, 7(2), 123-135. Retrieved from http://jab.polinema.ac.id/index.php/jab/article/view/173/pdf

Safitri, F., Rahayu, M., \& Indrawati, N. K. (2016). Pengaruh Kualitas Pelayanan dan Citra 
Proceeding ICOGISS 2019

Page 910-919. ISBN: 978-602-6 988-75-1

Web Jurnal Online: jurnal.unmuhjember.ac.id By: Dery Shafwan; Nurul Qomariah; Jekti Rahayu

The Influence of Quality of Service, Facilities and Location of Customer Satisfaction

Perusahaan Terhadap Kepuasan Pelanggan dan Loyalitas Pelanggan Service Center [ Studi Pada Pelanggan Samsung Service Center di Kota Malang ]. Jurnal Ekonomi Bisnis, 1-15.

Setyawati, W. A., Rifai, M., \& Sasmito, C. (2018). Pengaruh Kualitas Pelayanan , Fasilitas , Harga dan Citra Institusi Terhadap Kepuasan Pasien. Madani, Jurnal Politik Dan Sosial Kemasyarakatan, 10(2), 50-63.

Subagiyo. (2015). Pengaruh Kualitas Pelayanan Akademik Dan Citra Institusi Terhadap Kepuasan Mahasiswa Lp3I Cilegon. Jurnal Lentera Bisnis, 4(1), 1-26.

Sugiyono. (2013). Metode Penelitian Pendidikan Pendekatan Kuantitatif, Kualitatif, dan $R \& D$. Bandung: Alfabeta.

Sutrisno, Cahyono, D., \& Qomariah, N. (2017). Analisis Kualitas Pelayanan , Kepercayaan Serta Citra Koperasi Terhadap Kepuasan Dan Loyalitas Anggota. Jurnal Sains Manajemen \& Bisnis Indonesia, 7(2), 157-174.

Tarinda, R., Zaini, A., \& Zebua, S. (2018). Kepuasan Pelanggan Pada Scissors Barbershop Malang. Jurnal Aplikasi Bisnis, 4(1), 2016-2019. Retrieved from http://jab.polinema.ac.id/index.php/jab/article/view/173/pdf

Tjiptono, F. (2007). Service, Quality \& Satisfaction. Yogyakarta: Andi.

Tjiptono, F., \& Candra, G. (2012). Pemasaran Strategik. Yogyakarta: Andi.

Verriana, R. I., \& Anshori, M. Y. (2017). Pengaruh Kualitas Layanan ( Service Quality ) Terhadap Loyalitas Melalui Kepuasan. Accounting and Managemen Journal, 1(1), 6379.

Yunus, \& Budiyanto. (2013). Pengaruh Kualitas Pelayanan dan Fasilitas Terhadap Kepuasan Pelanggan. Jurnal Ilmu \& Riset Manajemen, 3(12), 1-119. 